\title{
The Stenopodainae (Hemiptera, Heteroptera) of Argentina
}

\author{
Fernando Diez', María del Carmen Coscarón² \\ I Universidad Nacional de La Pampa, Facultad de Ciencias Exactas y Naturales. Avenida Uruguay 151, \\ (L 6300 CLB) Santa Rosa, La Pampa, Argentina 2 División Entomologia, Facultad de Ciencias Naturales \\ y Museo, Universidad Nacional de La Plata, Paseo del Bosque, CP 1900, La Plata, Argentina
}

Corresponding authors: Fernando Diez (fddiez@gmail.com); María del Carmen Coscarón (mcoscaron@fcnym.unlp.edu.ar)

Academic editor: T. Henry | Received 29 October 2013 | Accepted 16 July 2014 | Published 5 November 2014

http://zoobank.org/COOB076F-3E7E-4B2C-8E54-59A0F78ACFB9

Citation: Diez F, Coscarón MC (2014) The Stenopodainae (Hemiptera, Heteroptera) of Argentina. ZooKeys 452: 51-77. doi: $10.3897 /$ zookeys.452.6519

\begin{abstract}
In Argentina, 10 genera and 33 species of Stenopodainae (Hemiptera: Reduviidae) have been recorded. Diagnoses of the genera, subgenera and species are given, and an illustrated key to genera is provided. Six species are new records for Argentina and an additional seven species represent new records for provinces.
\end{abstract}

\section{Keywords}

Reduviidae, Stenopodainae, key, distribution, new record, Argentina

\section{Introduction}

The Stenopodainae are characterized by the presence of a large cell, usually pentagonal or hexagonal, in the venation of the hemelytra, formed by the cubital and postcubital veins and the apical and posterior cubital and postcubital crossveins (Barber 1930; Weirauch and Munro 2009). The antenniferous tubercles and juga (mandibular plates) are usually strongly produced anteriorly. The elongate and incrassate scapus is also an important subfamily character (Barber 1930; Schuh and Slater 1995).

This subfamily contains 113 genera with 713 species worldwide (Maldonado Capriles 1990). A total of 10 genera with 27 species have been recorded in Argentina (Coscarón 
in press). The Stenopodainae subfamily is monophyletic (Weirauch 2008, Weirauch and Munro 2009, Hwang and Weirauch 2012). This subfamily is phylogenetically closely related to the subfamily Triatominae and the genera Zelurus Burmeister and Opisthacidius Berg of the subfamily Reduviinae (Hwang and Weirauch 2012). Eggs are laid singly and loosely inside soil exposing their apices (Ambrose 1999); some species are nocturnal and can be captured by light traps (Villiers 1948 and personal observation).

Argentina - the geographical area considered in this report - lies in the Neotropical faunal region. The country covers an area of $2,791,810 \mathrm{~km}^{2}$ and is bordered by Uruguay, Brazil, Paraguay, Bolivia, and Chile. Approximately $75 \%$ of the country is occupied by arid and semiarid areas, but some places, such as the Yungas and Paranaense regions, are covered by rainforest.

The objective of this report is to provide an illustrated key of the genera of Stenopodainae from Argentina, including new diagnoses, geographical distribution records, and lists of species for each genus.

\section{Material and methods}

This study is based on material provided by the Museo Argentino de Ciencias Naturales (MACN) and the Museo de La Plata (MLP) (http://heteroptera.myspecies.info), Argentina. We have followed the terminology of Barber (1930) and Giacchi (1970, 1974). Distance from the anterior margin of the eyes to the apex of the antenniferous tubercles is the anteocular region. Distance from the posterior margin of the eyes to the pronotal collar is the postocular region.

Images were taken with a digital camera (PANASONIC DMC-S3) and a Wild M-stereomicroscope. The material was compared with photographs of type from the Naturhistoriska Riksmuseet of Stockholm, Sweden (http://www.nrm.se) and the American Museum of Natural History of New York (http://www.amnh.org). The distributions we list for Argentina were taken from Coscarón (in press). We used the program DIVA-GIS 7.1.7 (http://www.diva-gis.org) and the distribution of those specimens for which global positioning system data were available to construct the maps.

\section{Results}

Key to the genera of Stenopodainae for Argentina modified from Wygodzinsky and Giacchi (1994)

1a Scapus produced beyond insertion of the basiflagellomere (Fig. 1)

Pnirontis Stål (Figs 28-31)

1b Scapus not produced beyond insertion of basiflagellomere.........................2

2a First labial segment approximately twice as long as the second and third segments combined (Fig. 2) 

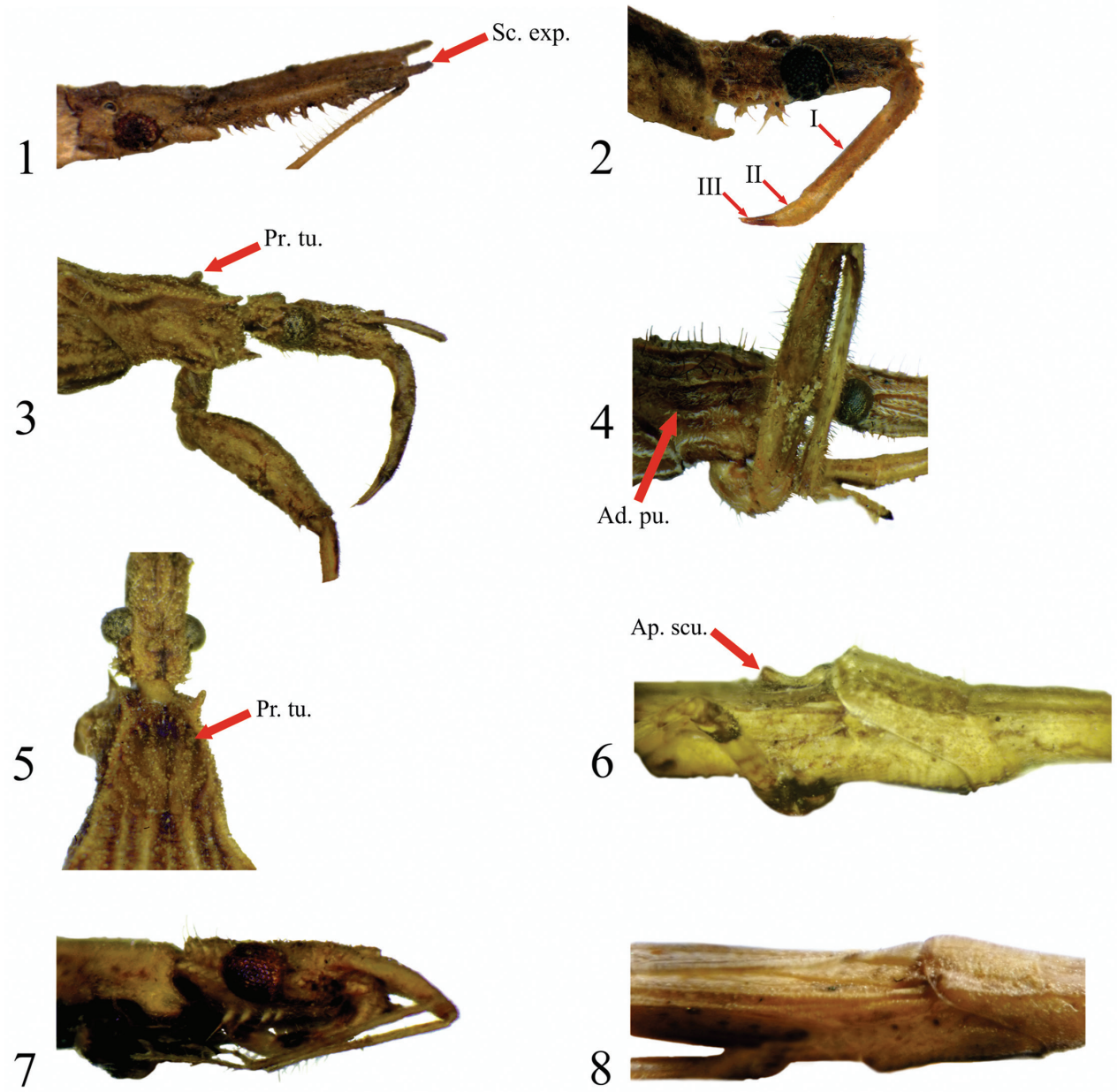

Figures I-8. Generic characters. I Head Pnirontis stali 2 Head Pygolampis spurca 3 Pronotum lateral view Ocrioessa cornutulus 4 Pronotum lateral view Stenopoda guaranitica 5 Pronotum dorsal view Ocrioessa cornutulus 6 Scutellum lateral view Seridentus maculosus 7 Head and pronotum lateral view Seridentus maculosus 8 Pronotum lateral view Ctenotrachelus sp. (Ad pu: adpressed pubescence; Ap scu: apex of scutellum; Pr tu: pronotal tubercles; Sc exp: expansions of scapus; I: first labial segment; II: second labial segment; III: third labial segment).

$2 \mathrm{~b} \quad$ First labial segment equal to or shorter than second and third segments com-

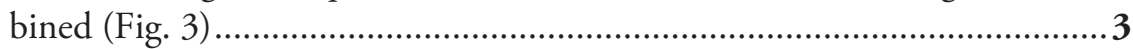

3a Prosternum behind coxae as long as or longer than coxae (Fig. 3) .............. 4

$3 \mathrm{~b} \quad$ Prosternum behind coxae shorter than coxae, or coxae inserted at hind margin of prosternum (Fig. 4) ....................................................................

4a Disc of anterior lobe of pronotum with 1+1 distinct tubercles (Figs 3, 5). First labial segment about as long as second segment (Fig. 3). Anterolateral angles of collar angles acutely spinous (Fig. 5). Fore coxae elongate cylindrical, about 


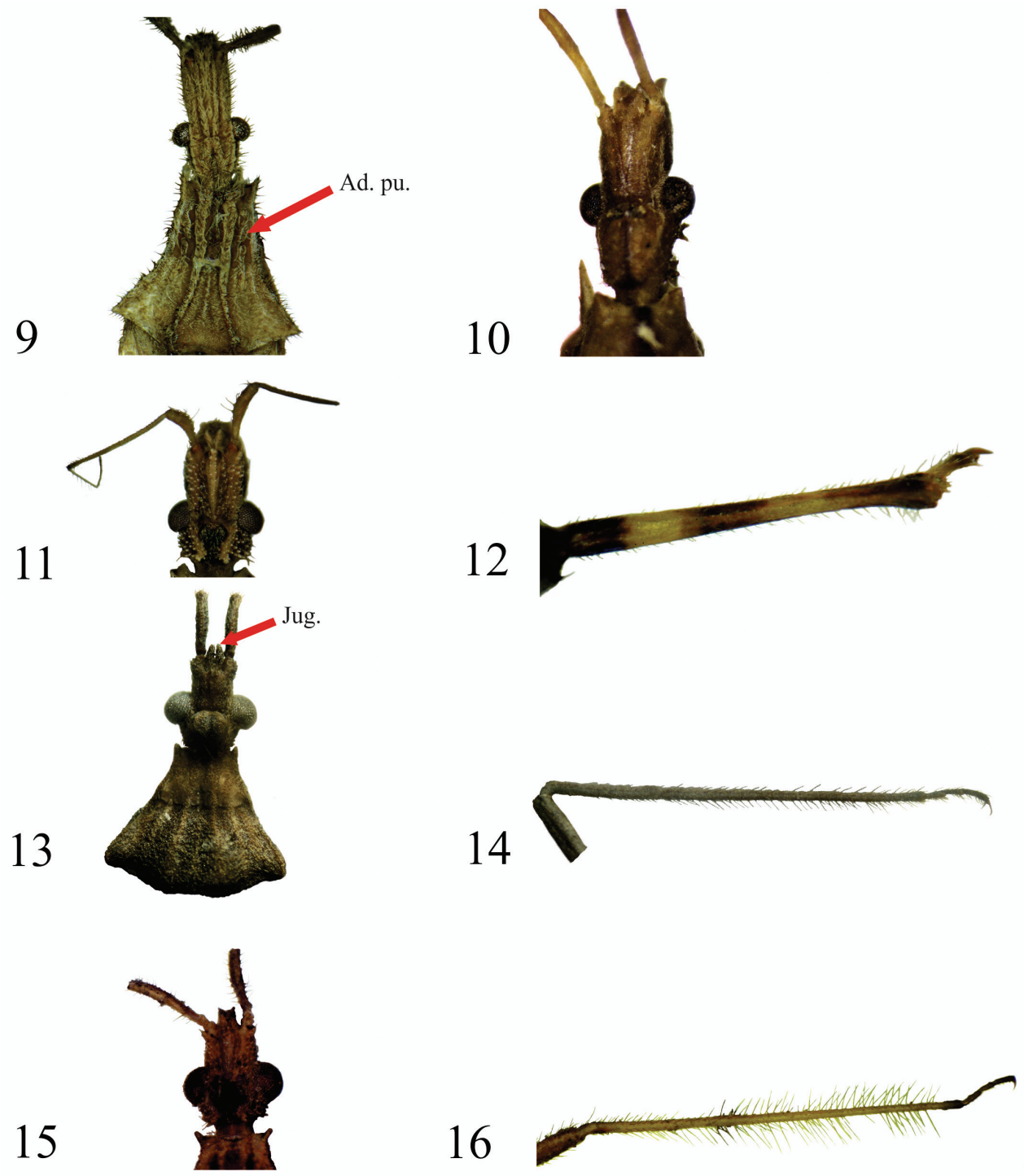

Figures 9-16. Generic characters. 9 Head dorsal view Stenopoda guaranitica 10 Head dorsal view Gnathobleda toba II Head dorsal view Oncocephalus validispinis 12 Tibiae ventral view Oncocephalus validispinis 13 Head and pronotum dorsal view Diaditus latulus 14 Tibiae dorsal view Diaditus latulus 15 Head dorsal view Narvesus carolinensis 16 Tibiae dorsal view Narvesus carolinensis. (Ad pu: adpressed pubescence; Jug: juga).

twice as long as wide (Fig. 3), hemelytral apical cubital and postcubital crossvein obsolete (Fig. 26) Ocrioessa Bergroth (Fig. 26)

$4 \mathrm{~b} \quad$ Disc of fore lobe of pronotum without $1+1$ distinct spine-like tubercles .....5 5a Apex of scutellum angularly raised or vertical (Fig. 6). Anteocular region as long as or slightly shorter than postocular region (Fig. 33). Two lines of 

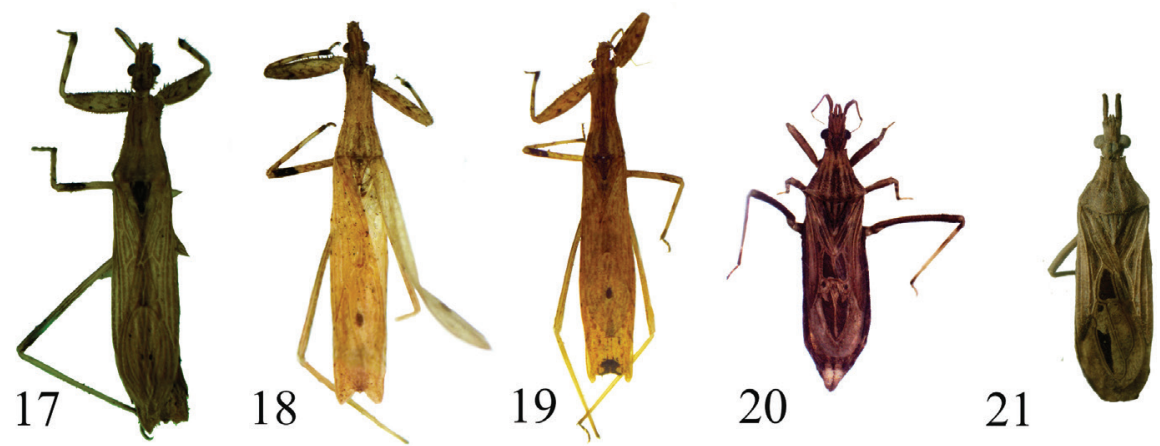

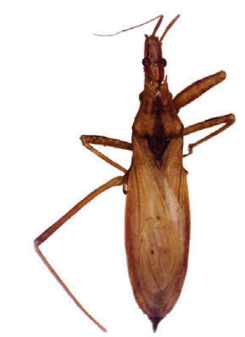

22

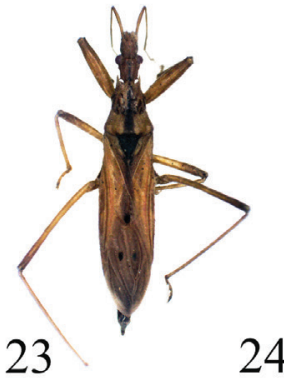

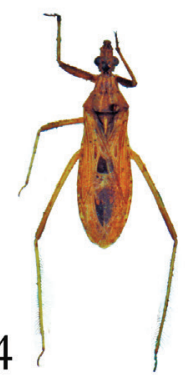
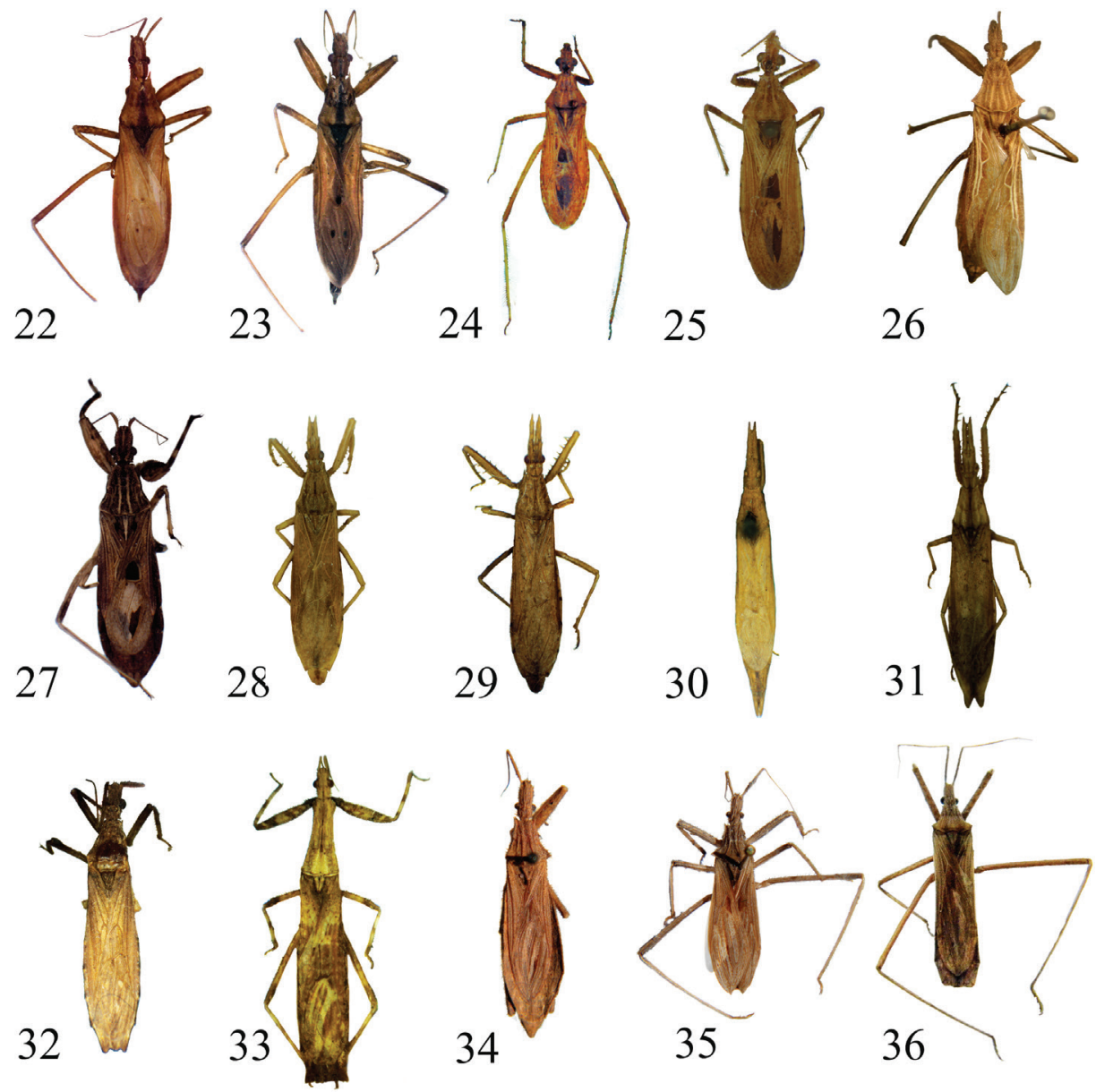

Figures 17-36. Dorsal view. 17 Ctenotrachelus minor Barber 18 Ctenotrachelus striatus Barber 19 Ctenotrachelus testaceus Barber 20 Diaditus pilosicornis Bergroth $\mathbf{2} 1$ Diaditus Latulus Barber. 22 Gnathobleda toba Giacchi 23 Gnathobleda litigiosa Stål 24 Narvesus carolinensis Stål 25 Narvesus minor Barber 26 Ocrioessa cornutulus (Berg) 27 Oncocephalus validispinis Reuter 28 Pnirontis edentula (Berg) 29 Pnirontis infirma Stål 30 Pnirontis scorpiona (Berg) 31 Pnirontis stali (Mayr) 32 Pygolampis spurca Stål 33 Seridentus maculosus (Haviland) 34 Stenopoda cana Stål 35 Stenopoda guaranitica Giacchi 36 Stenopoda subinermis Stål. 
spines on ventral side of head slightly surpassing the anterior and posterior margins of eyes, ventral spine about half or as long as posteroventral spines behind eyes (Fig. 7) Seridentus Osborn (Fig. 33)

5b Apex of scutellum horizontal (Fig. 8). Anteocular region twice as long as postocular region. Spine on ventral side of head much smaller than the ventrolateral one behind eyes (Fig. 7) .............. Ctenotrachelus Stål (Figs 17-19)

6a Body and appendages with dense, adpressed pubescence and numerous tiny, erect bristles (Figs 4, 9, 34-36). Margins of head nearly parallel-sided, in dorsal view, abruptly constricted at neck (Fig. 9). Foretibiae with elongate fossula spongiosa.

Stenopoda Laporte (Figs 34-36)

$6 \mathrm{~b} \quad$ Body glabrous or variously pubescent but not as above .7

7a Anteocular and postocular regions of equal length (Fig. 10). Body elongate fusiform, often five times or over five times as long as maximum width (Figs 22, 23). Male genitalia with cuplike posterior extension of pygophore completely covering parameres. Female genital area narrowly pointed posteriorly

Gnathobleda Stål (Figs 22, 23)

$7 \mathrm{~b} \quad$ Anteocular region longer than postocular region (Fig. 11). Body not elongate fusiform, broader, always less than five times as long as maximum width (Fig. 27). Male genitalia with parameres not covered, clearly visible. Female genital area not narrowly pointed posteriorly

8a Forefemora strongly incrassate, at least twice as thick as middle and hind femora (Fig. 27). Foretibia without distinct fossula spongiosa, or the latter not longer than diameter of tibia (Fig. 12)...... Oncocephalus Klug (Fig. 27)

8b Forefemora slender, less than twice as thick as mid and hind femora (Fig. 20)...9

9a Jugum subcylindrical, parallel, round apically, projecting well beyond apex of head (Fig. 13). Tibiae of hind legs with setae of a length less than twice the diameter of the tibia (Fig. 14)

Diaditus Stål (Figs 20, 21)

$9 \mathrm{~b}$ Jugum triangular bifurcated, apically sharp, not projecting beyond apex of head (Fig. 15). Tibae of hind legs with setae of length equal to four or five times the diameter of the tibia (Fig. 16). Narvesus Stål (Figs 24, 25).

\section{Taxonomy}

\section{Ctenotrachelus Stål}

Ctenotrachelus Stål, 1868: 127.

Type species. Ctenotrachelus macilentus Stål, 1872, subsequent monotypy.

Diagnosis. (After Barber 1930, Giacchi 1985, Maldonado Capriles 1994a) Anteocular region twice as long as postocular region. Setigerous tubercle on ventral side of head much smaller than the ventrolateral tubercle behind eyes. Pronotum longer than 


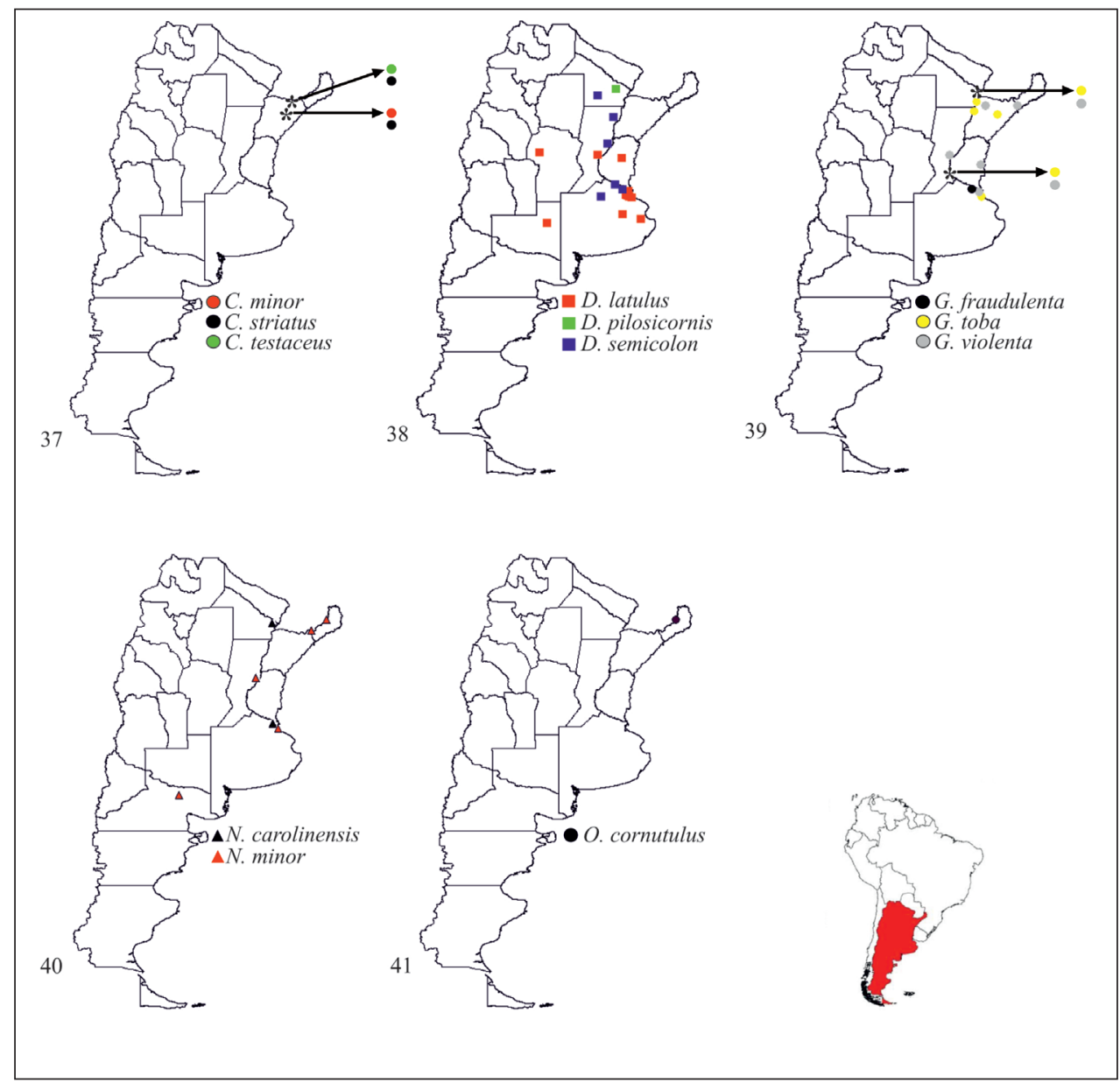

Figures 37-41. Geographical distributions of species of Stenopodainae in Argentina: 37 Ctenotrachelus Stål 38 Diaditus Stål 39 Gnathobleda Stål 40 Narvesus Stål 4 I Ocrioessa Bergroth.

wide, with the anterior lobe much longer than posterior one. Scutellar spine horizontal, metascutellar spine small. Fore femora sligthly incrassate. Anterior legs with third tarsal segment longer than first and second together.

\section{Ctenotrachelus minor Barber}

Ctenotrachelus minor Barber, 1930: 188, 200.

Diagnosis. (After Barber 1930, Maldonado Capriles 1995) Scapus three times as long as anteocular margin. Pronotum less than twice as long as head. Prefemur strongly incrassate. 
Material examined. Corrientes: $1 \hat{\jmath}$ (MLP) Colonia Carlos Pellegrini (28³1'54.0984"S, 579'49.8204"W), Coscarón M. coll.

Observation. New record for Argentina.

\section{Ctenotrachelus striatus Barber}

Ctenotrachelus striatus Barber, 1930: 197; Giacchi 1985: 67; Coscarón 2003: 361; Melo et al. 2004: 61.

Diagnosis. (After Barber 1930) Preocular region of head one third longer than postocular one. Lateral margins of pronotum unarmed. First two ventral abdominal segments carinate.

Material examined. Corrientes: $1 \lesssim$ (MLP) Colonia Carlos Pellegrini, Coscarón M. coll.

DistributioninArgentina.Corrientes:ColoniaCarlosPellegrini(28³1'54.0984"S, $\left.57^{\circ} 9^{\prime} 49.8204^{\prime \prime W}\right)$, Ituzaingó (2740'30.8742"S, 56²48'13.9428"W).

\section{Ctenotrachelus testaceus Barber}

Ctenotrachelus testaceus Barber, 1930: 189.

Diagnosis. (After Barber 1930) Postocular and preocular regions of head nearly equal or postocular region shorter than preocular one. Head behind eyes armed with three simple spines. Lateral margins of pronotum unarmed. First four segments of ventral abdominal segments carinate.

Material examined. Corrientes: $10^{\Uparrow}$ (MLP) Ituzaingó $\left(27^{\circ} 40^{\prime} 30.8742^{\prime \prime} \mathrm{S}\right.$, 56²8'13.9428"W), Coscarón M. col.

Observation. New record for Argentina.

\section{Diaditus Stål}

Diaditus Stål, 1859: 383.

Type species. Diaditus semicolon Stål 1859.

Diagnosis. (After Barber 1930, Giacchi 1973) Preocular region longer than postocular region. Juga long, robust and blunt apex, well extended beyond apices of antenniferous tubercles. Scapus shorter than head. First labial segment nearly equal to the second and third segments together. Hind tibiae with short setae, never reaching twice the diameter of the tibia. Anterior femora scarcely incrassate. Abdomen in ventral view with a median longitudinal carina, extending from sternum II to VI. 


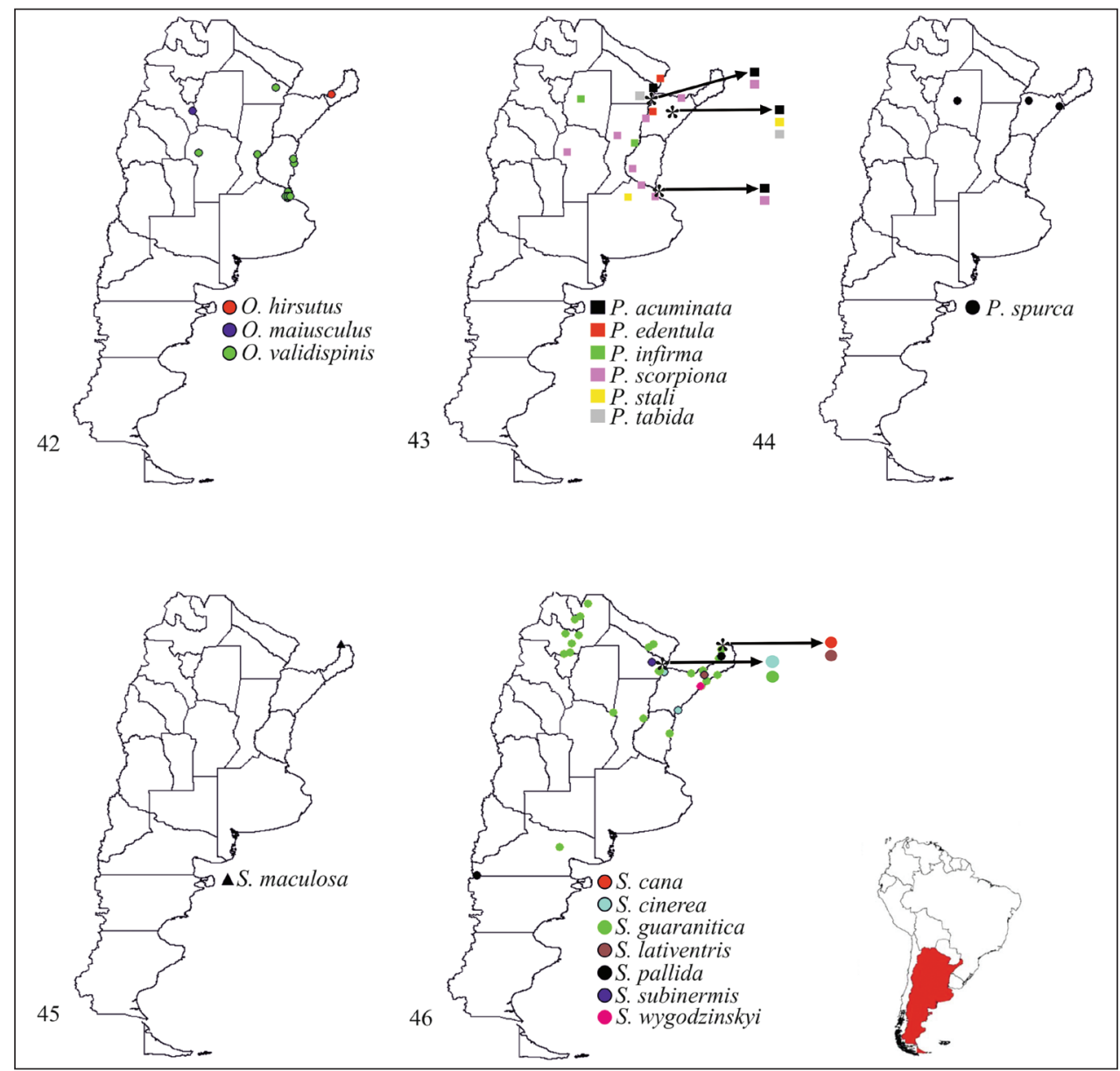

Figures 42-46. Geographical distributions of species of Stenopodainae in Argentina: 42 Oncocephalus Klug 43 Pnirontis Stål 44 Pygolampis Germar 45 Seridentus Osborn 46 Stenopoda Laporte.

\section{Diaditus latulus Barber}

Diaditus latulus Barber, 1930: 221; Wygodzinsky 1949: 66; Dispons 1971: 274; Giacchi 1982: 26; Maldonado Capriles 1990: 501; Martin-Park and Coscarón 2011: 56.

Diagnosis. (After Barber 1930, Giacchi 1982) Head short, less than twice as long as wide. Head shorter than pronotum. Males with setae in the ventral and lateral internal face of Pedicellus, seta length equal to twice the diameter of Pedicellus. Juga short, robust, subparallel, not reaching $1 / 4$ of scapus in males, but reaching almost half in females. Collar angles blunt.

Material examined. La Pampa: 1ठ (MLP) Santa Rosa (36³6'56.8902"S, 64¹7'49.7106"W), Diez F. Col.; Córdoba: $3{ }^{\wedge}$ (MACN) Departamento Calamuchita: El Sauce $\left(31^{\circ} 6^{\prime} 0.3312^{\prime \prime S}, 64^{\circ} 19^{\prime} 0.0084^{\prime \prime W)}\right.$. 
Distribution in Argentina. Buenos Aires: Daguerre (34'39'17.4636"S, $\left.58^{\circ} 28^{\prime} 53.2878^{\prime W}\right), \quad$ Delta $\quad\left(34^{\circ} 14^{\prime} 12.4188^{\prime \prime S}, \quad 58^{\circ} 34^{\prime} 10.1598^{\prime \prime W}\right), \quad$ Dolores (36 18'53.2044"S, 57 40'47.7798"W), Hurlingham (W34³5'52.4004"S58 38'8.7"), Ba-

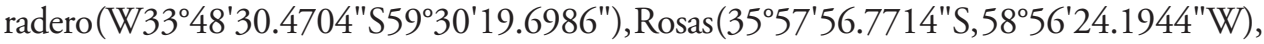

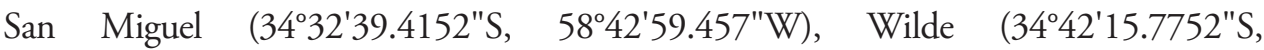

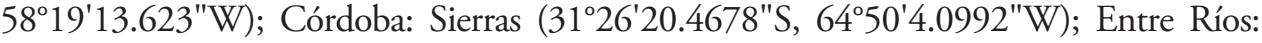
Villaguay $\left(31^{\circ} 51^{\prime} 53.0244 " \mathrm{~S}, 59^{\circ} 2^{\prime} 8.5956^{\prime \prime W}\right) ;$ Mendoza; Salta; San Juan; Santa Fe: Bridarolli (313' $\left.56.5998^{\circ} \mathrm{S}, 60^{\circ} 41^{\prime} 58.0518^{\prime \prime W}\right)$.

Observation. First record for La Pampa province.

\section{Diaditus pilosicornis Bergroth}

Diaditus pilosicornis Bergroth, 1907: 50; Melo et al. 2011.

Diagnosis. (After Barber 1930, Giacchi 1982) Males with setae on ventral and lateral internal face of Pedicellus, seta length three times the diameter of Pedicellus. Juga reaching more than $1 / 3$ of scapus in males and more than half in females. Prosternum glabrous, if tubercles or setae are present, these are scarce and conspiscuous. Collar angle obtuse. Fore femora in the ventral surface, basally with one spiniferous tubercle, the height is twice or more than setigerous tubercles of the trochanter.

Material examined. Chaco: $1 q$ (MLP) Chaco National Park.

Distribution in Argentina. Chaco: Chaco National Park (2648'24.9984"S, $59^{\circ} 26^{\prime} 36.4986^{\prime \prime W)}$.

\section{Diaditus semicolon Stål}

http://heteroptera.myspecies.info/taxonomy/term/1828

http://www2.nrm.se/en/het_nrm/s/diaditus_semicolon.html

Diaditus semicolon Stål, 1859: 383; Berg 1879: 278; Lethierry and Severin 1896: 86;

Pennington 1921: 22; Barber 1930: 220; Giacchi 1982: 22; Maldonado Capriles 1990: 501; Nanni et al. 2011: 34; Dellapé and Carpintero 2012: 130.

Diaditus annulipes Berg, 1883: 112; Lethierry and Severin 1896: 86; Pennington 1921:

22; Coscarón 1998: 2.

Diagnosis. (After Barber 1930, Giacchi 1982, Blinn 2009) Males with setae on ventral and lateral internal face of pedicellus, seta length three times the diameter of pedicellus. Juga reaching $1 / 5$ of scapus in males and $1 / 3$ in females. Fore femora with one or two setigerous tubercles, not larger than setigerous tubercles of the trochanter.

Material examined. 10 (MLP) Typus Diaditus annulipes Berg synonymized by Wygodzinsky 1949, 1:66, 67. (Geographic origin not given). Salta: 3 ㅇ, Embarcación

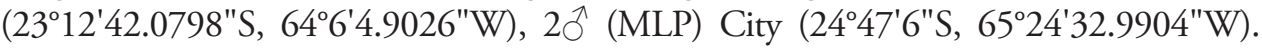


Mendoza $q$ (MLP) Typus Diaditus annulipes Berg synonymized by Wygodzinsky 1949, 1:66-67.

Distribution in Argentina. Buenos Aires: Baradero (33\%48'30.4704"S, 59³0'19.6986"W), Chacabuco (34²38'22.4304"S, 60²8'9.9726"W), Partido de Cam-

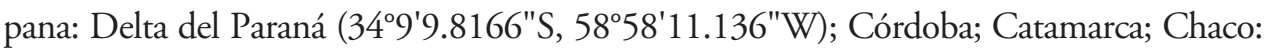

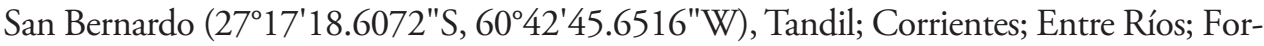
mosa; Jujuy; La Pampa; La Rioja; Mendoza; Misiones; Neuquén; Salta; San Juan; San Luis; Santa Fe: Colonia Mascías (3048'7.6032"S, 600'19.6266"W), Departamento General Obligado, Lanteri (2850'27.765"S, 59³8'9.981"W); Santiago del Estero; Tucumán.

Observation. First record for Salta province.

Remarks. The species currently assigned to the taxon is listed in Coscarón et al. (2014).

\section{Gnathobleda Stål}

Gnathobleda Stål, 1859: 380.

Type speccies. Gnathobleda fraudulenta Stål 1859.

Diagnosis. (After Wygodzinsky and Giacchi 1986) Sericeous pilosity. Anteocular and postocular portions of equal length. Large, pointed, laterally compressed juga. Presence of $1+1$ conspicuous tubercles on the pronotum. More or less developed posterior projections on the connexival segments.

Note. Wygodzinsky and Giacchi (1986) synonymised Pnohirmus Stål, with Gnathobleda Stål. Latter, Wygodzinsky and Giacchi (1994) in the key to the genera of the Stenopodainae of the new world they included the subgenera Ganthobleda (Gnathobleda) and Gnathobleda (Pnohirmus). In this article they did not mentioned the species for each subgenera. We do not use the subgenera of Gnathobleda due to this confusion.

\section{Gnathobleda fraudulenta Stål}

Gnathobleda fraudulenta Stål, 1859; Nanni et al. 2011: 34.

Diagnosis. (After Wygodzinsky and Giacchi 1986) Head with a simple setigerous tubercle. Juga triangular. Prosternal processes conspicuous, spinelike. Undersurface of fore femora with two rows of processes.

Distribution in Argentina. Buenos Aires: Partido de Campana: Delta del Paraná (349'9.8166"S, 5858'11.136"W).

\section{Gnathobleda litigiosa Stål}

http://www2.nrm.se/en/het_nrm/l/gnathobleda_litigiosa.html 
Diagnosis. (After Wygodzinsky and Giacchi 1986) Length less than $14 \mathrm{~mm}$. Genae conspicuously projecting beyond base of rostrum. Connexival segments light-colored with apical portion dark. Undersurface of fore femora with two series of processes, one setigerous, one spiniferous.

Material examined. $2 \hat{\jmath}$ (MLP) between Corrientes and Formosa (unspecified locality). Observation. New record for Argentina.

\section{Gnathobleda toba Giacchi}

Gnathobleda toba Giacchi, 1970: 126; Maldonado Capriles 1990: 503; Melo et al. 2004: 61 .

Diagnosis. (After Wygodzinsky and Giacchi 1986) Total length 14 mm or more. Some of the sublateral setigerous spines of the postocular region of the head bifurcate. Genae conspicuously projecting beyond base of rostrum, connexival segments concolorous. Undersurface of fore femora with one series of spiniferous processes.

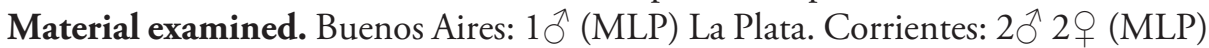
Bella Vista (28 30'27.8274"S, 59²'39.6492"W), $10^{\Uparrow}$ (MLP) between Corrientes and Formosa (unspecified locality). Santa Fe: $1 \widehat{\jmath}$ (MLP) Rosario.

Distribution in Argentina. Buenos Aires: Buenos Aires City (343' $13.5102^{\prime \prime S}$, $\left.58^{\circ} 22^{\prime} 53.4678^{\prime \prime W}\right)$, La Plata (3455' $\left.8.9616 " \mathrm{~S}, 57^{\circ} 57^{\prime} 21.495^{\prime \prime W}\right)$; Chaco: General Vedia (265' 58.728"S, 58³9'41.3958"W), Río de Oro (2656'6.0858"S, 5840'19.5414"W); Corrientes: Bella Vista, Colonia Carlos Pellegrini (28³2'5.4312"S, 570'10'27.5196"W).

Observation. First record for Santa Fe.

\section{Gnathobleda violenta (Stål)}

Pnohirmus violentus Stål, 1859: 384; Giacchi 1985: 66; Coscarón 2003: 361. Gnathobleda violenta Wygodzinsky and Giacchi, 1986: 141.

Diagnosis. (After Wygodzinsky and Giacchi 1986) Sublateral setigerous spines of postocular region of the head absent, simple or at most fused at base. Genae not conspicuously projecting beyond base of rostrum. Head without setigerous spines. Juga imperceptible in lateral view. Prosternal processes small, rounded, underside of femora with one row of spiniferous processes.

Distribution in Argentina. Buenos Aires: Delta (34'14'12.4188"S, $58^{\circ} 34^{\prime} 10.1598^{\prime \prime W)}$; Chaco: General Vedia (265'59.1234"S, 58³9'42.015"W), Río de

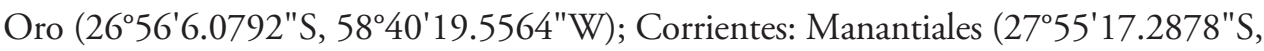
$\left.58^{\circ} 6^{\prime} 0.2874^{\prime \prime W}\right)$, Apóstol; Entre Ríos: Primero de Mayo (32¹5'24.21"S,

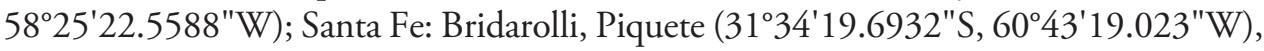
Rosario (3257'30.276"S, 60³9'32.688"W). 


\section{Narvesus Stål}

Narvesus Stål, 1859: 384.

Type species. Narvesus carolinensis Stål, 1859.

Diagnosis. (After Barber 1930, Giacchi 1973, Giacchi 1974) Juga acute at the tip and divergent, never extending beyond the length of tylus. Scapus shorter than the head. Hind legs with very long setae on the tibia, four or five times the diameter of the tibia.

\section{Narvesus carolinensis Stål}

Narvesus carolinensis Stål, 1859: 385; Diez and Coscarón 2014: 290.

Diagnosis. (After Barber 1930, Giacchi 1974) Anterior and middle tibia bifasciate. Fore femora without a row of spiniform tubercles on ventral face.

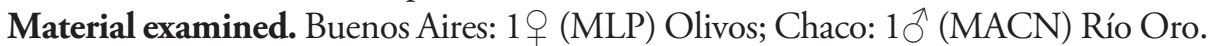

Distribution in Argentina. Buenos Aires: Olivos (34'30'39.1356"S, 58²9'44.7354"W); Chaco: Río Oro (2656'6.0792"S, 5840'19.5564"W).

\section{Narvesus minor (Barber)}

Narvesus minor Barber, 1930: 224; Giacchi 1974: 62; Maldonado Capriles 1990: 508; Carpintero 2009: 299; Diez and Coscarón 2014: 294.

Diagnosis. (After Barber 1930, Giacchi 1974) Anterior and mid tibiae trifasciate. Fore femora with a row of spiniform tubercles on ventral face.

Material examined. Santa Fe: $1 \overbrace{}^{\lambda}(\mathrm{MACN})$ Colonia Mascías; Neuquén: 10 (MLP) (unspecified locality).

Distribution in Argentina. Buenos Aires: Parque Costero del Sur (35 16'22.6266"S, $\left.\quad 57^{\circ} 15^{\prime} 50.724 " \mathrm{~W}\right)$; Misiones: Bocceti, Montecarlo

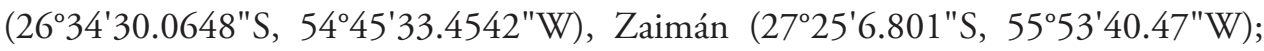
Neuquén; Río Negro: Lamarque $\left(39^{\circ} 25^{\prime} 12.2982^{\prime S}\right.$, 6542'0.9324"W). Santa Fe: Colonia Mascías (3048'1.9362"S, 600'48.6138"W).

\section{Ocrioessa Bergroth}

Ocrioessa Bergroth, 1918: 312.

Type species. Reduvius (Oncocephalus) notatus Klug 1830. 
Diagnosis. (After Barber 1930, Giacchi 1985) First labial segment about as long as second segment. Posterior ocular region shorter than anteocular region. Pronotum longer than wide, with deep transverse groove before the half. Disc of fore lobe of pronotum with $1+1$ distinct tubercles. Apical angles of segments II to VI terminated in triangular lobes, apical angles of segment VII ending in two acute lobes directed posteriorly.

\section{Ocrioessa cornutulus (Berg)}

http://heteroptera.myspecies.info/taxonomy/term/2052

Rhyparoclopius cornutulus Berg, 1879: 277; Lethierry and Severin 1896: 85; Pennington 1921: 22; Coscarón 1998: 509.

Ocrioessa cornutulus Giacchi 1985: 68; Maldonado Capriles 1990: 509.

Diagnosis. (After Barber 1930, Giacchi 1985) Diameter of the gula much wider, being about twice as wide as the diameter of base of second labial segment. Scapus about twice as long as the preocular region. Discal spines of anterior lobe situated before the constriction with tubercles reduced.

Material examined. Misiones: 1 ㅇ (MLP) Montecarlo.

Distribution in Argentina. Chaco; Misiones: Montecarlo (26034'23.4294"S, $54^{\circ} 45^{\prime} 29.7462^{\prime \prime W)}$.

Remarks. The species currently assigned to the taxon is listed in Coscarón et al. (2014).

\section{Oncocephalus Klug}

Reduvius (Oncocephalus) Klug, 1830: 2. Type species: Reduvius (Oncocephalus) notatus Klug, 1830.

Oncocephalus Fieber, 1860: 42.

Diagnosis. (After Giacchi, 1984) Body oval. Eyes of male large, eyes of female smaller, with several rather distinct setigerous tubercles behind eyes. Antennae and tibiae with long setae, particularly in males. Basal segment of rostrum shorter than the two apical segments together. Fore femora strongly incrassate and distinctly spinose (with one or two row(s) of teeth on the ventral side).

\section{Oncocephalus hirsutus Giacchi}

Oncocephalus hirsutus Giacchi, 1984: 57; Maldonado Capriles 1990: 514.

Diagnosis. (After Giacchi 1984, Barber 1930) Pedicellus with long setae, more than three times the diameter of segment in males. The lateral tubercles of pronotum cov- 
ered with stiff setae. Fore femora with seven spines ventrally and dorsally covered by conspicuous setigerous tubercles.

DistributioninArgentina. Misiones: Loreto $\left(27^{\circ} 18^{\prime} 59.925^{\prime \prime}\right.$, 55 $\left.55^{\circ} 31^{\prime} 58.8462 " \mathrm{~W}\right)$.

\section{Oncocephalus maiusculus Giacchi}

Oncocephalus maiusculus Giacchi, 1984: 58; Maldonado Capriles 1990: 515; Martin-Park and Coscarón 2011: 57.

Diagnosis. (After Barber 1930, Giacchi 1984) Scapus, in the male, (in dorsal internal lateral view) with setae on the distal half or basal third. Setae length equal to half the diameter of scapus. Posterior lobe of pronotum brown and smooth.

Distribution in Argentina. Catamarca: Los Alamitos (28²8'59.4372"S, $\left.65^{\circ} 13^{\prime} 8.2698 \mathrm{\prime W}\right)$.

\section{Oncocephalus validispinis Reuter}

Oncocephalus validispinis Reuter, 1882: 714; Giacchi 1984: 55; Maldonado Capriles 1990: 521; Martin-Park and Coscarón 2011: 57; Melo et al. 2011.

Oncocephalus mazzai Costa Lima, 1941: 342; Wygodzinsky 1949: 67.

Diagnosis. (After Barber 1930, Giacchi 1984) Scapus (in dorsal internal lateral view) with three setae shorter than the diameter of scapus in male and two in females. Setae shorter than the diameter of scapus. Posterior lobe of pronotum with medial longitudinal lines and carina. Two light brown bands on either side of carina.

Material examined. Chaco: $1 \hat{\jmath}$ (MLP) Chaco National Park.

Distribution in Argentina. Buenos Aires: Delta (34'14'12.4188"S, $\left.58^{\circ} 34^{\prime} 10.1598^{\prime \prime W}\right)$, Haedo (34²38'39.714"S, 58³5'43.6272"W), Hurlingham

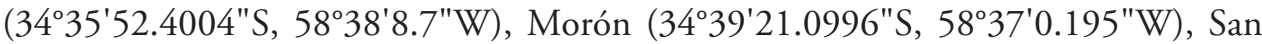

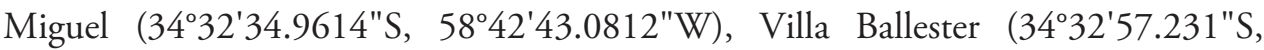
$\left.58^{\circ} 33^{\prime} 31.6902^{\prime \prime W}\right)$, Ciudad Universitaria (34²3'46.5018"S, 58 24'17.2218"W); Chaco: Chaco National Park (26²8'24.9984"S, 59²6'36.4986"W); Córdoba:

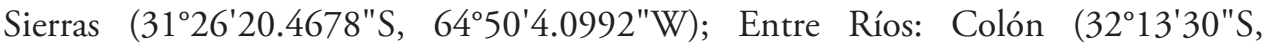

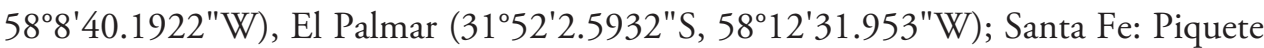
(313' $\left.17.9826 " \mathrm{~S}, 60^{\circ} 42^{\prime} 32.6736 " \mathrm{~W}\right)$; Santiago del Estero.

\section{Pnirontis Stål, 1859}

Pnirontis Stål, 1859: 381.

Type species. Pnirotis scutellaris Stål 1859; subsequent designation by Van Duzee 1916. 
Diagnosis. (After Barber 1930, Giacchi 1985, Giacchi 1988a) Body elongate longitudinally, fusiform and depressed. First labial segment almost three times longer than the second and third together, the second almost twice as long as the third. Scapus strongly incrassate, extended in an apical process that extends beyond the insertion of the second segment.

\section{Pnirontis (Centromelus) Stål, 1868}

Diagnosis. (After Wygodzinsky and Giacchi 1994) Antenniferous tubercles unarmed, or provided with minute spines. First segment of mid and hind tarsi shorter than second. Posterior angles of connexival segments varied.

Type species. Pnirontis (Centromelus) spinosissimus Stål, 1859; subsequent designation by Van Duzee (1916).

\section{Pnirontis acuminata Barber}

Pnirontis acuminata Barber, 1930: 156; Giacchi 1985: 64; Giacchi 1988a: 6. Pnirontis (Centromelus) acuminata Melo et al. 2004: 61.

Diagnosis. (After Barber 1930, Giacchi 1985, Maldonado Capriles 1986, 1994b) Head longer than pronotum. Scapus equal to length of preocular margin of head. Spines of fore femora long, two or three times as long as diameter of femur. Connexivum marked with fuscous at incisures. Male unknown.

Distribution in Argentina. Buenos Aires: Delta (58 17'37.0644"S, 58 17'37.0644"W); Chaco: General Vedia (2656'0.153"S, 58³9'42.015"W), Río Oro (26.56'6.0792"S, 58 $\left.46^{\circ} 19.5564 " \mathrm{~W}\right)$; Corrientes: Colonia Carlos Pellegrini (283'․ $\left.5.4312 " \mathrm{~S}, 57^{\circ} 10^{\prime} 27.5196 " \mathrm{~W}\right)$.

\section{Pnirontis edentula (Berg)}

Centromelus edentulus Berg, 1879: 275; Coscarón 1998: 4.

Pnirontis edentula Lethierry \& Severin, 1896: 81; Barber 1930: 171; Wygodzinsky 1949: 68; Maldonado Capriles 1990: 525.

Pnirontes (Centromelus) edentulus Pennington, 1921: 22.

Diagnosis. (After Barber 1930) Scapus shorter than pronotum and about twice as long as preocular margin of head. Antenniferous tubercles long, about 1/4 longer than eye. Pronotum longer than wide.

Material examined. Buenos Aires: 19 (MLP) (unspecified locality). Corrientes: 1 우 (MLP) San Roque (2834'31.1736"S, 58²'31.032"W). Between Corrientes and 
Formosa provinces: $1 \hat{\jmath} 1 \uparrow(\mathrm{MLP})$ (unspecified locality). Formosa: $2 \hat{\sigma}$ (MLP) Laguna Oca $\left(26^{\circ} 14^{\prime} 0.0234^{\prime \prime S}, 58^{\circ} 11^{\prime} 59.9742^{\prime \prime W}\right)$.

Distribution in Argentina. Argentina: Buenos Aires.

Observation. First record for Corrientes and Formosa provinces.

\section{Pnirontis infirma Stål}

Pnirontis infirma Stål, 1859: 382.

Diagnosis. (After Barber 1930) Scapus shorter than pronotum and about twice as long as preocular margin of head. Pronotum almost as wide as long. Antenniferous tubercles shorter, about equal to length of eyes.

Material examined. Chaco: 1 q (MLP) Resistencia (27²7'23.3742"S, 58 58'55.776"W); Jujuy: $20^{\wedge} 29$ Reyes (MLP) (unspecified locality); Santa Fe: $1{ }^{\jmath}$ (MLP) Colonia Mascías (3047'55.8348"S, 600'52.3218"W); Santiago del Estero: $10^{\Uparrow}$ (MLP) Beltrán (2749'43.6506"S, 64³'35.5068"W).

Observation. New record for Argentina.

\section{Pnirontis scorpiona (Berg)}

Centromelus scorpionius Berg, 1879: 276; Coscarón 1998: 6.

Pnirontes (Centromelus) scorpionius Pennington, 1921: 22.

Pnirontis corpionia Barber, 1930: 161; Wygodzinsky 1949: 68; Giacchi 1985: 65; Maldonado Capriles 1990: 526; Coscarón 2003: 361.

Pnirontis scorpionica Lethierry \& Severin, 1896: 81.

Pnirontis (Centromelus) scorpioni Giacchi, 1988a: 6.

Pnirontis scorpionia Carpintero \& De Biase, 2011: 35

Diagnosis. (After Barber 1930, Giacchi 1985) Female head with tylus produced into a single process. Juga minute. Scapus longer than head. Genae well extended beyond apex of antenniferous tubercles. Anterior trochanters armed with a spine. Foretibiae with two series of spines, an inner series of 7-8 spines and an outer series of 4 spines. Corium and connexivum immaculate.

Material examined. Buenos Aires: 19 (MLP) Buenos Aires City. Chaco: $1 q$ (MLP) Resistencia. Formosa: $1 q$ (MLP) (unspecified locality). Santiago del Estero: 19 (MLP) (unspecified locality).

Distribution in Argentina. Buenos Aires: Baradero (3348'30.4704"S, 59³0'19.6986"W), Buenos Aires City (34³6'13.5102"S, 58²2'53.4678"W), Isla Martín García (34²10'53.6154"S, 58¹5'5.6592"W); Chaco: Resistencia $\left(27^{\circ} 27^{\prime} 23.3742^{\prime \prime S}, 58^{\circ} 58^{\prime} 55.776^{\prime \prime W}\right)$; Córdoba: Sierras (31 $266^{\prime} 20.4678^{\prime \prime S}$, 64º50'4.0992"W); Corrientes: Estación Puerto Valle (29²'0.225"S, 59¹1'31.113"W), 
Ituzaingó (2740'30.8742"S, 5648'13.9428"W), San Cayetano (27³4'14.9988"S, $\left.58^{\circ} 41^{\prime} 40.9986^{\prime W}\right)$; Entre Ríos: Victoria (32³7'18.9048"S, 60'27.3312"W); Santa Fe: San Cristóbal (30¹8'30.2142"S, 61¹4'19.9176"W).

\section{Pnirontis stali (Mayr)}

Pnirontis (Centromelus) stali Mayr, 1865: 437; Melo et al. 2004: 61. Centromelus stali Berg, 1879: 295.

Pnirontes (Centromelus) stali Pennington, 1921: 22.

Diagnosis. Translated from Mayer (1865): Genae slightly longer than antenniferous tubercles. Scapus spiny underneath and almost 1/3 longer than the head. Pale yellow, in part dark, abdominal margin with small dark spots.

Material examined. 1 우 (MLP), $3 \hat{\jmath}$ (MLP) Geographic origin not given.

Distribution in Argentina. Buenos Aires: Chacabuco (34³8'22.4304"S, 60²8'9.9726"W); Corrientes: Colonia Carlos Pellegrini (28³2'5.4312"S, 570'10'27.5196"W); Misiones.

\section{Pnirontis tabida Stål}

Pnirontis tabida Stål, 1859: 381.

Pnirontis (Centromelus) tabida Melo et al., 2004: 61.

Diagnosis. (After Barber 1930) Female tylus extending into a single stout process beyond apex of antenniferous tubercles. Juga very short, scarcely visible. Scapus, including long apical spine, 1/4 longer than head. Genae short, extending but little beyond apex of antenniferous tubercles. Foretibiae armed only with an inner series of spines and with preapical spur; corium and connexivum immaculate.

Distribution in Argentina. Argentina: Corrientes: Colonia Carlos Pellegrini (283'ㄴ. $4312^{\prime \prime}$ S, $\left.57^{\circ} 10^{\prime} 27.5196 \mathrm{~W}\right)$.

\section{Pygolampis Germar}

Pygolampis Germar, 1817: 286.

Type species. Acanthia denticulata Rossi, Junior synonym of Cimex bidentatus Goeze, 1778.

Diagnosis. (After Barber 1930) Scapus not produced beyond insertion of basiflagellomere. First labial segment approximately twice as long as second and third segments. Scapus unarmed beneath. Head dorsally armed with two prominent tubercles. 


\section{Pygolampis pectoralis (Say)}

Reduvius pectoralis Say, 1832: 11.

Pygolampis pectoralis Pennington, 1921: 22.

Diagnosis. (After Barber 1930) Scapus little if any longer than head. Head just behind eyes armed with a large ramose spine, followed by one or two smaller ones.

Distribution in Argentina. Misiones.

\section{Pygolampis spurca Stål}

Pygolampis spurca Stål, 1859: 379.

Diagnosis. (After Barber 1930) Scapus twice or as long as head. Basiflagellomere finely pilose with setae longer than diameter of the segment.

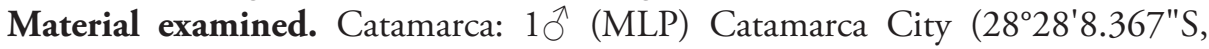
65\%46'44.2986"W), 1 ( (MLP) (unspecified locality); Corrientes: 19 (MLP) Santo Tomé (28 33'0.6696"S, 56 $\left.{ }^{\circ} 2^{\prime} 56.8062^{\prime \prime W}\right), 1$ ( 1 (MACN) Manantiales (275' $\left.28.0704 " S, 58^{\circ} 6^{\prime} 9.7914 " \mathrm{~W}\right)$; Formosa: 19 (MLP) (unspecified locality); Mis-

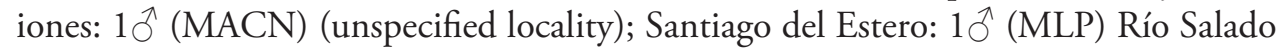
(unspecified locality).

Observation. New record for Argentina

\section{Seridentus Osborn}

Seridentus Osborn, 1904: 195.

Type species. Seridentus denticulatus Osborn, 1904.

Diagnosis. (After Maldonado Capriles 1994a) Anteocular space as long as or slightly shorter than postocular space. Two lines of setigerous tubercles on ventral side of head slightly surpassing the anterior and posterior margins of eyes. Spines about half as long as posteroventral setigerous tubercles behind eyes. Scutellar spine angulate, raised or vertical. Profemur moderately incrassate. Anterior legs with third tarsal segment twice as long as first and second combined.

\section{Seridentus latissimus Giacchi}

Seridentus latissimus Giacchi, 1998: 31.

Diagnosis. (After Giacchi 1998) Scapus three times as long as anteocular region of head. 
Lateral margins of pronotum with a row of small to setigerous tubercles. Pronotum less.

Pronotum less than twice as long as head. Juga and scutellar spines nearly porrect.

Distribution in Argentina. Misiones: Iguazú (255 $\left.57^{\prime} 2.289^{\prime \prime S}, 54^{\circ} 12^{\prime} 43.329^{\prime \prime W}\right)$.

\section{Seridentus maculosus (Haviland)}

Seridentus maculosus Haviland, 1931: 136.

Seridentus maculosus: Wygodzinsky, 1949: 69.

Diagnosis. (After Maldonado Capriles 1994a) Scapus twice as long as anteocular region of head. Lateral margins of pronotum with a row of small setigerous tubrecles. Pronotum less than twice as long as head. Juga and scutellar spines nearly porrect. Clavus, corium and membrane sparsely spotted with brown.

Material examined. Misiones: 1 우 (MACN) Iguazú (255'2.289"S, $54^{\circ} 12^{\prime} 43.329^{\prime \prime W)}$.

Observation. New record for Argentina.

\section{Stenopoda Laporte}

Stenopoda Laporte, 1832: 26.

Type species. Stenopoda cinerea Laporte, 1832.

Diagnosis. (After Barber 1930, Giacchi 1969, Giacchi 1988b) First labial segment shorter than the second and third segments combined. Postocular region shorter than preocular one. Body and appendages with dense, adpressed pubescence and numerous tiny, erect bristles. Margins of head nearly parallel-sided in dorsal view, abruptly constricted at neck. Two median dorsal carinae $(1+1)$ more or less elevated.

\section{Stenopoda (Megastenopoda) Giacchi}

Stenopoda (Megastenopoda) Giacchi, 1988b: 48.

Type species. Stenopoda subinermis Stål, 1859: 384.

Diagnosis. (After Giacchi 1988b) Total length of 23 to $35 \mathrm{~mm}$. Fossula spongiosa of $1 / 3$ to $1 / 2$ the length of the foretibiae.

\section{Stenopoda cana Stål}

Stenopoda cana Stål, 1859: 384; Giacchi 1969: 11; Maldonado Capriles 1990: 540. 
Diagnosis. (After Giacchi 1988b) Abdominal segments 1-5 divergent, the rest convergent. Pronotal setae longer than tubercles height. Tubercles conical and thick.

Material examined. Santiago del Estero: $1 \delta^{-1}$ (MLP) (unspecified locality).

Distribution in Argentina. Misiones: Puerto Iguazú (25³5'50.895"S, $54^{\circ} 34^{\prime} 42.873$ "W).

Observation. First record for Santiago del Estero province.

\section{Stenopoda lativentris Giacchi}

Stenopoda lativentris Giacchi, 1969: 13; Bachmann 1999: 215, 224.

Diagnosis. (After Giacchi 1988b) Abdominal segments 1-5 divergent, the rest convergent. Pronotal setae two times longer than tubercles height. Subcylindrical tubercles, longer than wide.

Distribution in Argentina. Misiones: Pindapoy $\left(27^{\circ} 45^{\prime} 2.592^{\prime \prime} S\right.$, $\left.55^{\circ} 47^{\prime} 28.4856^{\prime \prime W}\right)$, Puerto Iguazú (253' 50.6862"S, 54³4'43.4922"W).

\section{Stenopoda pallida Giacchi}

http://research.amnh.org/iz/types_db/images/Stenopoda_pallida.jpg

Stenopoda pallida Giacchi, 1969: 13; Giacchi 1988b: 56.

Diagnosis. (After Giacchi 1988b) Side of the abdomen parallel. Pronotal setae curved and shorter than height of tubercle. Tubercles semispherical. Fossula spongiosa of $1 / 5$ or $1 / 6$ foretibia length.

Distribution in Argentina. Misiones: Eldorado (26 25'1.506"S, 54³6'41.3706"W); Río Negro: El Bolsón (4158'10.9236"S, 71³2'14.3694"W).

\section{Stenopoda subinermis Stål}

Stenopoda subinermis Stål, 1859: 384; Melo et al. 2011: 7.

Diagnosis. (After Giacchi 1988b). Sides of the abdomen parallel. Pronotal setae shorter than tubercles height. Semispherical tubercles. Foretibiae with fossula spongiosa of equal length to half the length of the tibia.

Material examined. Chaco: $1 \sigma^{\Uparrow}$ (MLP) Chaco National Park.

Distribution in Argentina. Chaco: Chaco National Park (26²8'24.9984"S, $59^{\circ} 26^{\prime} 36.4986^{\prime \prime W)}$. 


\section{Stenopoda (Stenopoda) Giacchi, 1988}

Stenopoda (Stenopoda) Giacchi, 1988b: 48.

Type species. Stenopoda cinerea Laporte, 1832.

Diagnosis. (After Giacchi 1988b) Total length of 18 to $26 \mathrm{~mm}$. Fossula spongiosa of $1 / 7$ to $1 / 4$ the length of the foretibiae.

\section{Stenopoda cinerea Laporte}

Stenopoda cinerea Laporte, 1832: 26; Barber 1930: 203; Quintanilla et al. 1976: 129; Froeschner 1988: 648.

Diagnosis. (After Giacchi 1988b) Spots of the connexival segments dark brown, ellipsoidal. Fossula spongiosa of $1 / 5$ to $1 / 4$ the length of the foretibiae.

Material examined. Chaco: 1 \% (MLP) Fontana (272 $25^{\prime} 1.0452^{\prime \prime}$, $\left.59^{\circ} 1{ }^{\prime} 54.6882 \mathrm{WW}\right)$; Santiago del Estero: $1 \hat{\jmath}$ (MLP) (unspecified locality).

Distribution in Argentina. Chaco: Fontana; Córdoba: as south as Córdoba; Corrientes: Departamento Monte Caseros (30¹5'9.4212"S, 57³7'20.604"W), Departamento San Luis del Palmar (2730'40.464"S, 58³3'30.4518"W).

Observation. First record for Chaco and Santiago del Estero provinces.

\section{Stenopoda guaranitica Giacchi}

Stenopoda guaranitica Giacchi, 1969: 19; Giacchi 1988b: 52; Maldonado Capriles 1990: 541; Bachmann 1999: 214; Coscarón 2003: 361.

Diagnosis. (After Giacchi 1988b) Total length between 18 and $26 \mathrm{~mm}$. Pronotal setae one and a half times longer than tubercles height. Fossula spongiosa of $1 / 7$ to $1 / 5$ the length of the foretibiae.

Material examined. Río Negro: 10 (MLP) Pemona $\left(39^{\circ} 29^{\prime} 9.2142^{\prime \prime} S\right.$, $\left.65^{\circ} 36^{\prime} 33.5592^{\prime \prime W}\right)$; Formosa: $20^{\wedge}$ (MLP) Isla Oca $\left(26^{\circ} 15^{\prime} 13.6722^{\prime \prime S}, 58^{\circ} 11^{\prime} 15.846^{\prime \prime W}\right)$, 1 우 (MLP) Río Paraj. 1 우 (unspecified province and locality), $3 \hat{\circ}$ (unspecified locality).

Distribution in Argentina. Chaco: Apóstol, Resistencia (27\%26'37.0356"S, $\left.58^{\circ} 58^{\prime} 7.8924 " W\right)$, Río de Oro (5840'19.5564"S, 5840'19.5564"W); Córdoba;

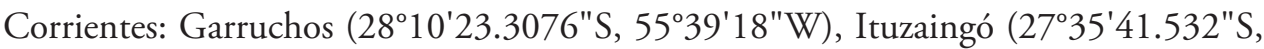
$\left.56^{\circ} 41^{\prime} 56.022^{\prime \prime W}\right)$, Santo Tomé (28 $\left.32^{\prime} 51.507^{\prime \prime S}, 56^{\circ} 2^{\prime} 14.3232^{\prime W}\right)$; Entre Ríos: El Palmar (31 $\left.51^{\circ} 51.5808^{\prime \prime S}, 58^{\circ} 12^{\prime} 30.5346 " \mathrm{~W}\right)$; Formosa: El Coatí (2543'59.8794"S, $\left.59^{\circ} 37^{\prime} 59.8794 " \mathrm{~W}\right)$, Palo Santo $\left(25^{\circ} 33^{\prime} 49.7304^{\prime \prime S}, 59^{\circ} 20^{\prime} 10.5252^{\prime \prime W}\right)$; Jujuy: Cali-

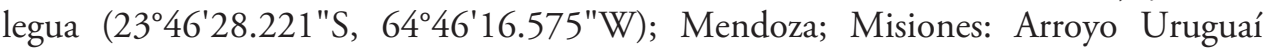
(255' $\left.32.157^{\prime \prime S}, 54^{\circ} 35^{\prime} 58.1136^{\prime W}\right)$, Eldorado (262 $\left.25^{\prime} 1.506^{\prime \prime S}, 54^{\circ} 36^{\prime} 41.3706^{\prime W}\right)$, 


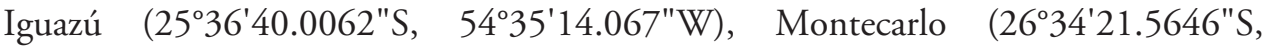

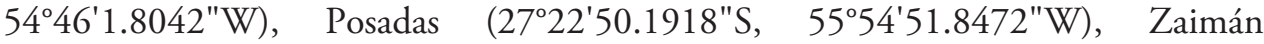
(27⒉ 6.801 "S, $\left.\quad 55^{\circ} 53^{\prime} 40.47^{\prime \prime W}\right), \quad$ Departamento Concepción: Panembí

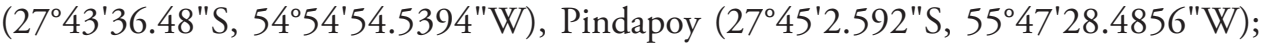
Santa Fe: Departamento De Garay: Colonia Mascías (3047'55.8348"S, $\left.60^{\circ} 0^{\prime} 52.3218 \mathrm{~W}\right)$; Salta: Departamento Anta: La Forestal $\left(24^{\circ} 55^{\prime} 0.0114 " \mathrm{~S}\right.$,

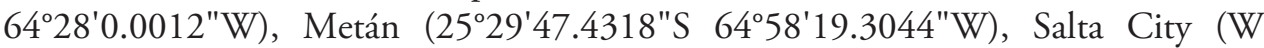

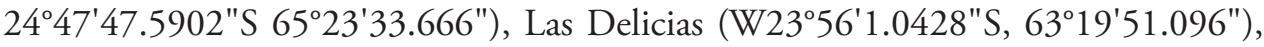
Urundel (233' $\left.28.8288^{\circ} \mathrm{S}, 6^{\circ} 23^{\prime} 50.9994^{\prime W}\right)$, Departamento Orán: Tablillas

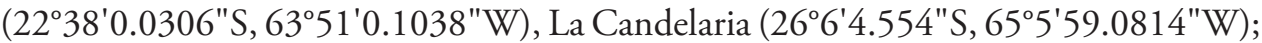

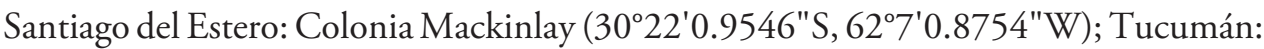
San Pedro de Colalao (26¹4'4.2504"S, 65²9'19.9674"W).

Observation. First record for Río Negro province.

\section{Stenopoda wygodzinskyi Giacchi}

http://research.amnh.org/iz/types_db/images/Stenopoda_wygodzinskyi.jpg

Stenopoda wygodzinskyi Giacchi, 1969: 19; Maldonado Capriles, 1990: 541; Coscarón 2003: 61.

Diagnosis. (After Giacchi 1988b) Setae of scapus of length equal to its diameter. Pronotal setae three times longer than tubercles height. Fossula spongiosa of $1 / 7$ to $1 / 6$ the length of the foretibiae.

Distribution in Argentina. Corrientes: Santo Tomé (W28³3'6.6378"S, $\left.56^{\circ} 2^{\prime} 43.52 "\right)$.

\section{Acknowledgments}

Special thanks to D. L. Carpintero (Museo Argentino de Ciencias Naturales "Bernardino Rivadavia") for lending specimens. We thank Dr. T. Henry (Systematic Entomology Laboratory, USDA, c/o National Museum of Natural History, Smithsonian Institution) and anonymous reviewer for revising and improving the manuscript. This work was supported by the Consejo Nacional de Investigaciones Científicas y Técnologicas (CONICET) and Agencia Nacional de Promoción Científica y Tecnológica of Argentina.

\section{References}

Ambrose DP (1999) Ovipositions behaviour. Assassin bugs. Science publishers and New Delhi, India, New Hampshire, 202-206. 
Bachmann AO (1999) Catálogo de los tipos de Heteroptera (Insecta) conservados en el Museo Argentino de Ciencias Naturales. Revista del Museo Argentino de Ciencias Naturales, nueva serie 1: 191-230.

Barber HG (1930) Essay on the subfamily Stenopodinae of the New World. Entomologica Americana 10: 149-238.

Berg C (1879) Hemiptera Argentina Enumeravit Specisque Novas. Anales de la Sociedad Científica Argentina, 9-316.

Berg C (1883) Addenda et emendata ad Hemiptera Argentina. Anales de la Sociedad Cientifica Argentina 16: 5-32, 73-87, 105-125, 180-191, 231-241, 285-294.

Bergroth E (1907) Notes on American Hemiptera. III The Acanthosomatinae of North America. Entomological News 18: 48-51.

Bergroth E (1918) Hendecasa Generum Hemipterorum Novorum vel Subnovorum. Annales Musei Nationalis Hungarici 16: 298-314.

Blinn RL (2009) New records for the genus Diaditus (Hemiptera: Heteroptera: Reduviidae: Stenopodainae) in America north of Mexico. Zootaxa 2125: 57-62.

Carpintero DL (2009) Insecta: Hemiptera: Heteroptera. In: Athor J (Ed.) Parque Costero del Sur: Naturaleza, conservación y patrimonio cultural. Fundación de Historia Natural "Félix de Azara", 528 pp.

Carpintero DL, De Biase S (2011) Los Hemiptera Heteroptera de la Isla Martín Garcías (Buenos Aires, Argentina). Historia Latural 1: 27-47.

Coscarón MC (1998) Los ejemplares tipo de Reduviidae (Heteroptera) depositados en la colección del Museo de La Plata. Serie Técnica y Didáctica, Museo de La Plata 29: 1-9.

Coscarón MC (2003) Anexo I: Biodiversidad de chinches terrestres (Insecta: Heteroptera) en los Esteros de Iberá: Inventario faunístico en la provincia de Corrientes. In: Alvarez BB (Ed.) Fauna del Iberá. Eudenes, Corrientes, 359-387.

Coscarón MC (in press) Reduviidae. Catalogue of the Heteroptera or true bugs of Argentina. Zootaxa.

Coscarón MC, Diez F, Basset C, Lopez N (2014) Heteroptera. A web resource for Heteroptera typus from Museum of La Plata. http://heteroptera.myspecies.info

Costa Lima A (1941) Consideraçôes sobre alguns Reduvídeos da subfamilia "Stenopodinae". Revista Brasileira de Biología 1: 337-342.

Dellapé PM, Carpintero DL (2012) Relevamiento de los Heteroptera (Insecta: Hemiptera) de las sierras de Tandil, provincia de Buenos Aires, Argentina. Revista del Museo Argentino de Ciencias Naturales 14: 125-134.

Diez F, Coscarón MC (2014) Revision of the genus Narvesus Stål, 1859 (Hemiptera: Heteroptera: Reduviidae: Stenopodainae) and a new record for Argentina. Zootaxa 3811: 289-296.

Dispons P (1971) Notes sur quelques Stenopodinae du Muséum Zoologique de l' Université Humbolt (Hemiptera, Heteroptera, Reduviidae). Mittelungen der Zoologischen Museum Berlin 47: 273-283. doi: 10.1002/mmnz.19710470205

Fieber FX (1861) Die europäischen Hemiptera: Halbflüger (Rhynchota, Heteroptera). Gerold's Sohn, Vienna, 1-444. [1860, 1-108; 1861, 109-444] 
Fitzpatrick U, Murray TE, Paxton RJ, Brown JF (2007) Building on IUNCN regional red lists to produce lists of species of conservation priority: a model with Irish Bees. Conservation Biology 21: 1324-1332. doi: 10.1111/j.1523-1739.2007.00782.x

Froeschner RC (1988) Family 36 Reduviidae. In: Henry TJ, Froeschner RC (Eds) Catalogue of the Heteroptera, or True Bugs, of Canada and the Continental United States. E.J. Brill, Leiden, New York, KØbenhavn, Köln, 616-651.

Germar EF (1817) Reise durch Österreich, Tyrol nach Dalmatien und in das Gebiet von Ragusa 2: 1-323. [Brockhaus, Leipzing]

Giacchi JC (1969) Revisión del género Stenopoda Laporte, 1833 (Hemiptera, Reduviidae, Stenopodainae). Physis 29: 1-26.

Giacchi JC (1970) Notas y descripciones sobre Stenopodainos de la Argentina. I. Gnathobleda toba sp.nov. (Heteroptera, Reduviidae). Physis 30: 125-129.

Giacchi JC (1973) Revisión de los Stenopodainos Americanos. II. Acerca de la posición taxonomica de Diaditus Stål y Narvesus Stå (Reduviidae, Heteroptera). Caracteres distintivos y comunes. Physis 32: 1-13.

Giacchi JC (1974) Revisión de los Stenopodainos Americanos. III. El género Narvesus Stål, 1859 (Heteroptera, Reduviidae). Physis 33: 53-64.

Giacchi JC (1982) Revisión de los Stenopodainos Americanos. V. El género Diaditus Stål, 1859 (Heteroptera, Reduviidae). Physis 41: 9-27.

Giacchi JC (1984) Revisión de los Stenopodainos Americanos. VI. Las especies americanas del género Oncocephalus Klug, 1830 (Heteroptera- Reduviidae). Physis 42: 39-62.

Giacchi JC (1985) Revisión de los Stenopodainos Americanos. VII. Redescripción de los géneros Pnirontis Stål, 1859; Pnohirmus Stål, 1859; Ctenotrachelus Stål, 1868; Ocrioessa Bergroth, 1918 y Kodormus Barber, 1930 (Heteroptera: Reduviidae). Physis 43: 61-70.

Giacchi JC (1988a) Revisión de los Stenopodainos Americanos. VIII. Estudio preliminar acerca del status genérico de Pnirontis Stål, 1859 y Rutuba Torre Bueno, 1914. (Heteroptera, Reduviidae). Physis 46: 5-13.

Giacchi JC (1988b) Revisión de los Stenopodainos Americanos. IX. El género Stenopoda Laporte, 1833 (Heteroptera, Reduviidae). Enmiendas y notas adicionales. Physis 46: 47-59.

Giacchi JC (1998) Una nueva especie del género Seridentus Osborn, 1904 (Stenopodainae, Reduviidae, Heteroptera). Physis 56: 31-32.

Göeze JAE (1778) Entomologische beyträge zu des Ritter linne' zwölfen Ausgabe des natursystems. Vol 2. Leipzing, 72+352.

Halffter G, Favila ME (1993) The Scarabaeinae (Insecta: Coleoptera): an animal group analising, inventorying and monitoring biodiversity tropical rainforest and modified landscapes. Biology International 27: 15-21.

Haviland MD (1931) The Reduviidae of Kartabo, Bartica District, British Guiana. Zoologica 7: 129-154.

Hwang WS, Weirauch C (2012) Evolutionary history of assassin bugs (Insecta: Hemiptera: Reduviidae): insights from divergence dating and ancestral state reconstruction. PLoS ONE 7: 1-12. doi: 10.1371/journal.pone.0045523 
Klug JCF (1830) Symbolae physicae, seu icones et descriptiones insectorum, quae ex itinere per Africam Borealem, Asiam. G. Hemprich et C. H. Ehrenberg Studio novae illustratae redierunt. Part 2: a-f, 10 plates, 242.

Kremen C (1994) Biological inventory using target taxa: a case study of the butterflies of Madagascar. Ecological Applications 4: 407-422. doi: 10.2307/1941946

Lethierry L, Severin G (1896) Catalogue Général des Hémiptères. Volumes 3. F. Hayez, Bruxelles and Berlin 3: 1-275.

Laporte FL (1832) Essai d'une classification systematique de l'ordre des Hémiptères (HémiptèresHétéroptères Latr). Magazin de Zoologie (Guerin) 2: 2-88, plates 51-55.

Maldonado Capriles J (1986) The genus Pnirontis, the subinermis group of species (Heteroptera: Reduviidae: Stenopodainae). Journal of Agriculture of University of Puerto Rico 70: 9-18.

Maldonado Capriles J (1990) Systematic Catalogue of the Reduviidae of the World. Caribbean Journal of Science, Special Edition, 694 pp.

Maldonado Capriles J (1994a) A new species of Seridentus Osborn, 1904 and key to the species (Heteroptera: Reduviidae: Stenopodainae). Proceeding of the Entomological Society of Washington 96: 717-722.

Maldonado Capriles J (1994b) Pnirontis grandis n. sp. (Heteroptera: Reduviidae: Stenopodainae). Proceeding of the Entomological Society of Washington 96: 713-716.

Maldonado Capriles J (1995) A new Ctenotrachelus and notes about other species in the genus (Heteroptera: Reduviidae: Stenopodainae). Caribbean Journal of Science 31: 141-147.

Martin-Park A, Coscarón MC (2011) Assassin bugs (Hemiptera: Heteroptera: Reduviidae) of Uruguay: A synoptic catalogue as a contribution to the study of Austral biodiversity. Zootaxa 3006: 50-62.

Mayr G (1865) Diagnosen neuer Hemipteren II. Verhadlungen der Kaiserlich-königlichen Zoologisch-botanischen Geselleschaft in Wien 15: 429-446.

Melo MC, Dellapé PM, Carpintero DL, Coscarón MC (2004) Reduviidae, Miridae y Lygaeoidea (Hemiptera) recolectados en Colonia Carlos Pellegrini (Esteros de Iberá, Corrientes, Argentina). Revista de la Sociedad Entomológica Argentina 63: 59-67.

Melo MC, Dellapé PM, Carpintero DL, Montemayor SI (2011) Heteroptera (Hemiptera) from the Chaco National Park (Argentina). Zootaxa 2999: 1-19.

Nanni AS, Magnano AL, Carpintero DL (2011) Los Heteroptera (Insecta: Hemiptera) edáficos del INTA Delta del Paraná (partido de Campana, Buenos Aires). Variación espacial y temporal del elenco de las especies en distintos usos de la tierra. Delta del Paraná. Revista del Museo Argentino de Ciencias Naturales 13: 27-39.

Osborn H (1904) Notes on South American Hemiptera-Heteroptera. Ohio Naturalist 5: 195-204. Pennington MS (1921) Lista de los Hemipteros Heteropteros de la República Argentina. Segunda parte: Familia Aradidae, Neididae, Lygaeidae, Pyrrhocoridae, Tingididae, Enicocephalidae, Phymatidae, Reduviidae, Nabidae, Cimicidae, Miridae (parte). Buenos Aires, 17-28.

Quintanilla RH, Margheritis AE, Rizzo HF (1976) Catálogo de hemípteros hallados en la provincia de Corrientes (Argentina). Revista de la Sociedad Entomológica Argentina 35: 115-133.

Reuter OM (1882) Monographia generis Oncocephalus proximeque affinium. Acta Societatis Scientiarum Fennicae 12: 673-758, pl. 1-3. 
Say T (1832) Descriptions of new species of heteropterous Hemiptera of North America. New Harmony, Indiana, $39 \mathrm{pp}$.

Schuh RT, Slater JA (1995) True Bugs of the World (Hemiptera: Heteroptera): Classification and Natural History. Cornell University Press, Ithaca and London, 366 pp.

Stål C (1859) Till kännedomen om Reduvini. Öfversigt af Kongliga Svenska Vetenskaps-Akademiens Förhandlingar 16: 363-386.

Stål C (1868) Hemiptera Fabriciana I. Kongliga Svenska Vetenskaps-Akademiens Handlingar 7: $1-148$.

Stål C (1872) Enumeratio Hemipterorum: Bidrag till en företeckning öfver alla Hittils kanda Hemiptera, jemte systematiscka meddelanden. Part II. Kongliga Svenska Vetenskaps-Akademiens Handlingar 10: 1-159.

Van Duzee EP (1916) Check List of the Hemiptera (Exepting the Aphididae, Aleurodidae and Coccidae) of America, North of Mexico. New York Entomological Society, New York, $110 \mathrm{pp}$.

Villiers A (1948) Faune de L'Empire Français. IX. Hémiptères Réduviidés de L'Afrique Noire. Office de la Recherche Scientifique Coloniale, Paris, 488 pp.

Weirauch C (2008) Cladistic analysis of Reduviidae (Heteroptera: Cimicomorpha) based on morphological characters. Systematic Entomology 33: 229-274. doi: 10.1111/j.13653113.2007.00417.x

Weirauch C, Munro JB (2009) Molecular phylogeny of the assassin bugs (Hemiptera: Reduviidae), based on mitochondrial and nuclear ribosomal genes. Molecular Phylogenetics and Evolution 53: 287-299. doi: 10.1016/j.ympev.2009.05.039

Wygodzinsky P (1949) Elenco sistematico de los reduviiformes americanos. Instituto Medicina Regional Tucumán, Monografia 1: 1-102.

Wygodzinsky P, Giacchi JC (1986) A preliminary study about the generic status of Gnathobleda Stål, 1859 and Pnohirmus Stål, 1859 (Reduviidae: Stenopodainae). Physis 44: 141-145.

Wygodzinsky P, Giacchi JC (1994) Key to the genera of Stenopodainae of the New World (Insecta, Heteroptera, Reduviidae). Physis 49: 5-9. 